\title{
Credit Behaviour of Banks in the European Union in the Wake of Global Economic Crisis ${ }^{1}$
}

\author{
Stanislav Polouček, VSB - Technical University of Ostrava
}

\begin{abstract}
Recent financial crises hit many countries. The impact on Visegrad countries in credit area was not damaging. The main reason was stability and soundness of financial (banking) sectors in these countries and an adequate response of central banks as well as flexible management of commercial banks. Commercial banks, usually daughter companies of western banks, used above all domestic deposits for financing credits. This played a key role in credit area and helped to keep the financial system stable. It is important to underpin that responses to the crisis have been rather heterogeneous in central European countries and there are quite big disparities among Visegrad countries, too. In the paper developments and responses of the commercial banks to the crisis and their stability have been discussed on the basis of deposits, loans of monetary financial institutions to the non-financial sector, households, governments, lending for house purchase and credit for consumption in several EU countries. Net position of banks vis-á-vis foreign banks is taken into account, too.
\end{abstract}

JEL Codes: G01, G21

\section{Introduction}

Rapid financial sector development played a key role in the EU growth and convergence experience. For Visegrad countries (Poland, Hungary, Slovakia, the Czech Republic) foreign capital (in a form of foreign direct investments as well as in a form of various types of credits) was the basis for increasing integration with the rest of the EU. The widespread foreign ownership of banking sectors also contributed to capital inflows and the boom before the crisis (Debrun and Mathisen, p. 12). But in some eastern and central European countries this inflow of capital is considered to be excessive prior to the crises. Strong capital inflows are often associated with boosting credit growth and fuelling asset bubbles. Rapid credit growth is typically followed by an increase in non-performing loans. One can therefore expect foreign investors to be more cautious because of growing risk in countries experiencing a credit boom.

Central banks in Visegrad countries were less active in directly managing credit booms and capital inflows. It is good to say that it was quite difficult to be active for them, partly because of the EU free capital market. However, most central banks in this region took measures to rein in overall credit growth and/or the growth in foreign currency denominated credit (Gardó and Martin, p. 12). In some countries (Hungary, Poland) foreign currency denominated credits to households played an important role during exchange rate turbulences and as a mechanism of contagion of domestic economy - for instance in Poland around $80 \%$ of mortgages were denominated in CHF. High appreciation of PLN in 2007 increased credit risk in banking sector, demanded higher reserves and brought lower liquidity in financial sector.

Recent financial crisis spurred unprecedented government recapitalization programs and liquidity injections by central banks. The ECB and central banks in EU countries also supported liquidity in financial sector but this policy was quite selective. In many EU countries financial sector got an unprecedented government support: on average in the EU the state guarantees in favor of financial institutions were (October 2008-December 2009) more than 20 $\%$ GDP, guarantees effectively used by financial institutions around $8 \%$ of GDP (European Central Bank, 2010b). Only in seven countries (Bulgaria, the Czech Republic, Estonia, Italy, Lithuania, Malta and Romania) no program was approved or effective at all. In Visegrad

Publication of this paper was supported by the Czech Science Foundation within project GACR 402/08/0067 "Financial Integration of the EU New Member States with Eurozone". 
countries measures of central banks were less comprehensive in comparison to most other countries; lower intervention could be attributed to the relatively limited financial stress and sound financial (banking) sector.

The disparities of the effects of the financial crisis are rather large. There were several ways of contagion which worked at different strengths in the different countries. In general there was no or negligible exposure of central European countries to subprime or subprime-related assets (toxic assets). This is the main reason why central European countries performed relatively well until mid-September 2008. But in September 2008 the global economic and financial crisis started to impact foreign investor confidence and asset prices were influenced by an increase in risk aversion. The flight to safety was generally at the expense of the emerging economies: assets were shifted from these countries to more stable currencies and assets. In fact Visegrad countries were not hit hard via this channel. The growth of yield spreads and decline of stock markets were quite mild and short. But all these economies were hit hard via the real economic channels depending on the domestic economic development before the crisis.

Many studies argue that banks are granting less credits in crises because of worsening credibility of companies and growing risk of granted credits. They also argue that financial distress at western parent banks was associated with a significant impact on business lending to central and eastern European firms. In recent crisis banking sectors in several EU countries experienced a strong deceleration in credit and deposit growth and usually increase in nonperforming loans. It is important to underpin that the disparities among countries are rather large. The goal of the paper is to compare development of deposits and several types of loans in several EU countries and three Visegrad countries (the Czech Republic, Slovakia and Poland) and to find and compare how seriously they were hit by financial crisis and credit decrease.

\section{Data and credit development}

The paper is focusing on period January 2006 - June 2010. We use seven sets of monthly data at the end of the period (stocks): total outstanding amounts of deposits of monetary financial institutions (MFI); total outstanding amounts of loans granted by MFI; total outstanding amounts of loans granted by MFI to non-financial corporations; total outstanding amounts of loans granted by MFI to households and non-profit institutions serving households; total outstanding amounts of loans granted by MFI to government; total outstanding amounts of credits to consumption and total outstanding amounts of credits for house purchase. We focus on selected EU countries, namely Austria, Bulgaria, the Czech Republic, Finland, Greece, Hungary, Ireland, Poland, Portugal, Romania and Slovakia.

The development of loans shows no dramatic changes in most countries (Figure 1 and Figure 2) - in some of them (Portugal, Greece, Finland, Bulgaria) we can see lower dynamics after the crisis, but steadily growing amount of loans for the whole period. In Visegrad countries stagnation (Hungary, Slovakia) or growth (Poland, the Czech Republic) followed after a short drop of loans at the break of 2008/2009. The only country with relatively long decrease of loans was Ireland where stagnation starts in May 2008 and a long-term decline in January 2009.

The deposits developed in the same way as strong correlation between loans and deposits confirm (Table 1). In most EU countries loan indicators are strongly correlated with deposit indicators of MFI. Ireland is the only exception, low correlation is also in Slovakia. These data confirm the fact that in most European countries the loans of MFI are basically covered with the deposits and the amount of MFI loans is depending on available domestic sources (deposits) in these countries; it is the supply of deposits that is a limit. It is seen that deposit / loan ratio is relatively stable during the whole period in most countries (Table 2). The exceptions are Poland (loans are covered by deposits until half of 2008 and since then the 
amount of loans is higher than the amount of deposits) and Ireland (the amount of loans is higher than the amount of deposits until December 2008 and since then loans are covered by deposits). It is not possible to say that in countries where deposit / loan ratio is higher than 100 $\%$ the impact of financial crisis was milder than in countries where loans are more financed by outside credits. But in the case of Ireland the break in the deposits / loans ratio can be considered as a loss of confidence in Irish banks and in the case of Poland as a high confidence in Polish banking sector and Polish economy - Poland was the only EU country not experiencing GDP decrease during the recent crisis.

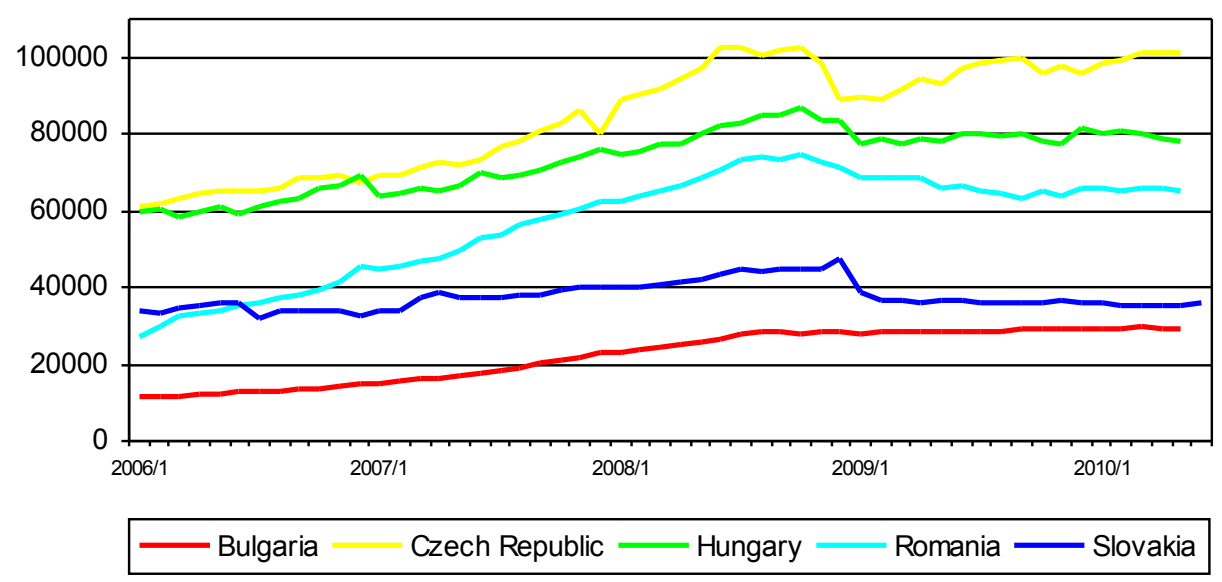

Figure 1. Loans of MFI in selected countries (1) (2006-2010, mil. EUR) Source: ECB

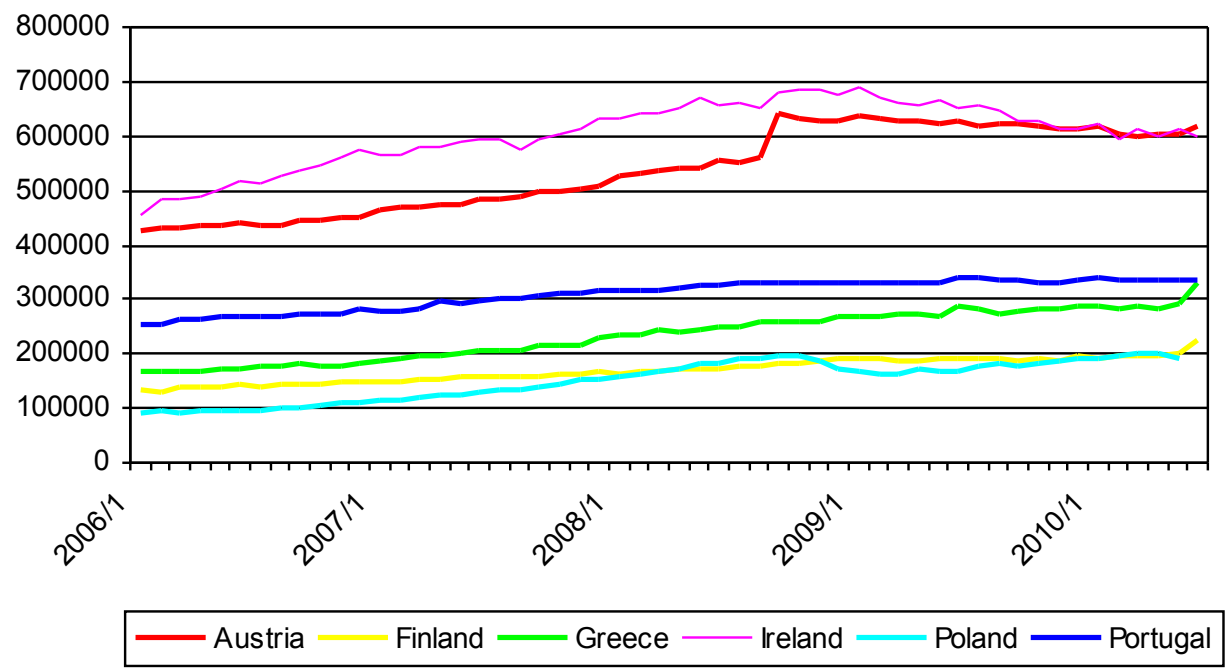

Figure 2. Loans of MFI in selected countries (2) (2006-2010, mil. EUR) Source: ECB

The deposits / loans ratio is often used as an indicator of credit vulnerability and higher values are considered as indicators of more stable financial sector. It really says a lot about the stability of MFI (banks), but nothing about the stability of the whole economy - governments, companies and households can get credit from other sources as well. Situation with huge government debt in Greece confirms this fact as well as relatively strong correlation between loans and deposits and relatively low correlations of loans to non-financial corporation / deposits and loans to household / deposits (Table 1). 


\begin{tabular}{|l|l|l|l|}
\hline & loans / deposits & $\begin{array}{l}\text { loans to non- } \\
\text { financial } \\
\text { corporations / } \\
\text { deposits }\end{array}$ & $\begin{array}{l}\text { loans to } \\
\text { households / } \\
\text { deposits }\end{array}$ \\
\hline Austria & 0,99298392 & 0,96841544 & 0,92834994 \\
\hline Bulgaria & 0,98243153 & 0,97392972 & 0,97538715 \\
\hline Czech Republic & 0,99669811 & 0,95567829 & 0,97980036 \\
\hline Finland & 0,96571379 & 0,95871247 & 0,96964026 \\
\hline Greece & 0,97252362 & 0,84725194 & 0,77758176 \\
\hline Hungary & 0,95068366 & 0,91534938 & 0,93921724 \\
\hline Ireland & 0,75679571 & 0,62420949 & 0,42670957 \\
\hline Poland & 0,97170241 & 0,95977865 & 0,93488103 \\
\hline Portugal & 0,93719882 & 0,98011191 & 0,94211127 \\
\hline Romania & 0,97090102 & 0,98296184 & 0,98178477 \\
\hline Slovakia & 0,88115486 & 0,78502990 & 0,64579222 \\
\hline
\end{tabular}

Table 1. Correlation coefficients between loans and deposits in selected EU countries (monthly data, January 2006-June 2010)

Foreign banks and their daughter companies started in Visegrad countries with loans to large companies, usually daughter companies of western financial conglomerates, financing their activities by their own (foreign) sources. Gradually they expanded into financial services to households and focused on lending and accepting deposits locally. That is why financing loans of MFI by foreign sources was not typical for Visegrad countries (the Czech Republic, Slovakia until the beginning of 2010 and Poland until half of 2007) before the recent financial crisis. Development of net investment position of MFI vis-á-vis foreign banks confirms (Figure 3 - Figure 5) that during the crisis the situation partly changed in Poland and Slovakia, but it stayed the same in the Czech Republic.

In Slovakia an economic development was seriously influenced by euro introduction in January, 2009. The financial sector was healthy and it has not been hit by financial crisis very seriously. Although bank lending standards were tightened throughout 2009, the slowdown of this process towards the year-end represented a moderately positive sign (NBS, 2010a, p. 21). The banks were very careful in financing companies but despite crisis the loans to nonfinancial corporations grew without any interruption until the end of 2008. A mild decrease and stagnation followed. Loans to households including lending for house purchase are permanently growing until now. The credit risk of households was not decreasing (NBS, 2010b, p. 3) but in March 2010 we can record the highest value of credits to households since November 2008. If banks have sources (deposits) they see households as less risky than enterprises. There was a huge but very short drop in total loans (as well as deposits) in January and February 2009 caused by drop in loans to foreign banks and similar drop in credits and deposits taken from foreign banks (Figure 5). Since then the amount of loans is at a standstill despite of mild growth of deposits.

\begin{tabular}{|c|c|c|c|c|c|}
\hline & 2006 & 2007 & 2008 & 2009 & 2010 \\
\hline Austria & 90,95 & 88,41 & 90,55 & 92,41 & 89,81 \\
\hline Bulgaria & 96,76 & 103,14 & 85,23 & 75,15 & 74,72 \\
\hline Czech Republic & 121,14 & 119,40 & 114,89 & 114,10 & 112,83 \\
\hline Finland & 74,28 & 71,74 & 74,36 & 69,43 & 70,18 \\
\hline Greece & 110,47 & 108,52 & 105,17 & 120,39 & 123,84 \\
\hline Hungary & 72,99 & 77,84 & 75,22 & 69,42 & 77,52 \\
\hline Ireland & 90,91 & 87,02 & 84,11 & 104,16 & 108,85 \\
\hline Poland & 122,16 & 115,42 & 101,08 & 90,16 & 92,64 \\
\hline Portugal & 85,59 & 80,69 & 80,46 & 80,09 & 86,17 \\
\hline Romania & 83,08 & 70,42 & 63,15 & 60,64 & 69,72 \\
\hline Slovakia & 104,34 & 108,59 & 104,97 & 107,65 & 114,13 \\
\hline
\end{tabular}


Table 2. Deposit / loan ratio in selected EU countries (in \%, January, 2006-2010)

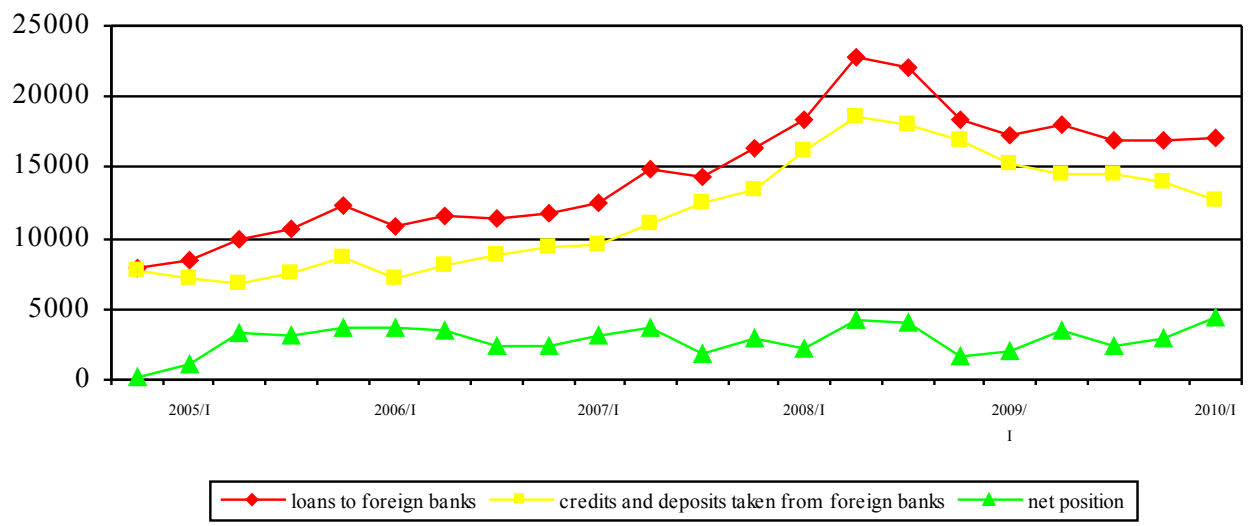

Figure 3. The Czech Republic: net position vis-á-vis foreign banks (2004-2010, mil. EUR) Source: The Czech National Bank

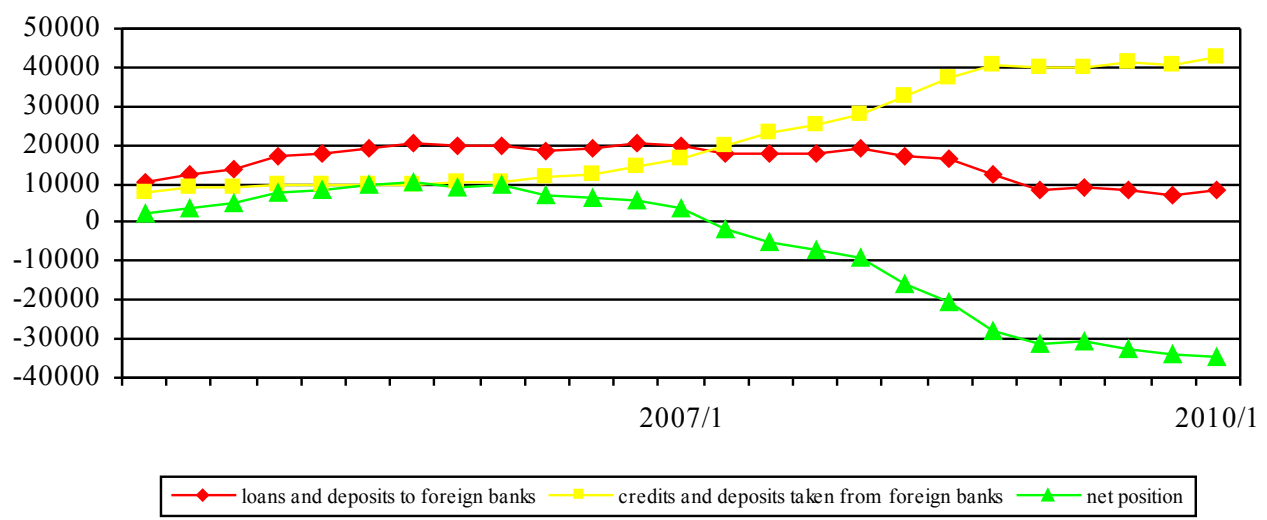

Figure 4. Poland: net position vis-á-vis foreign banks (2004-2010, mil. EUR) Source: The National Bank of Poland

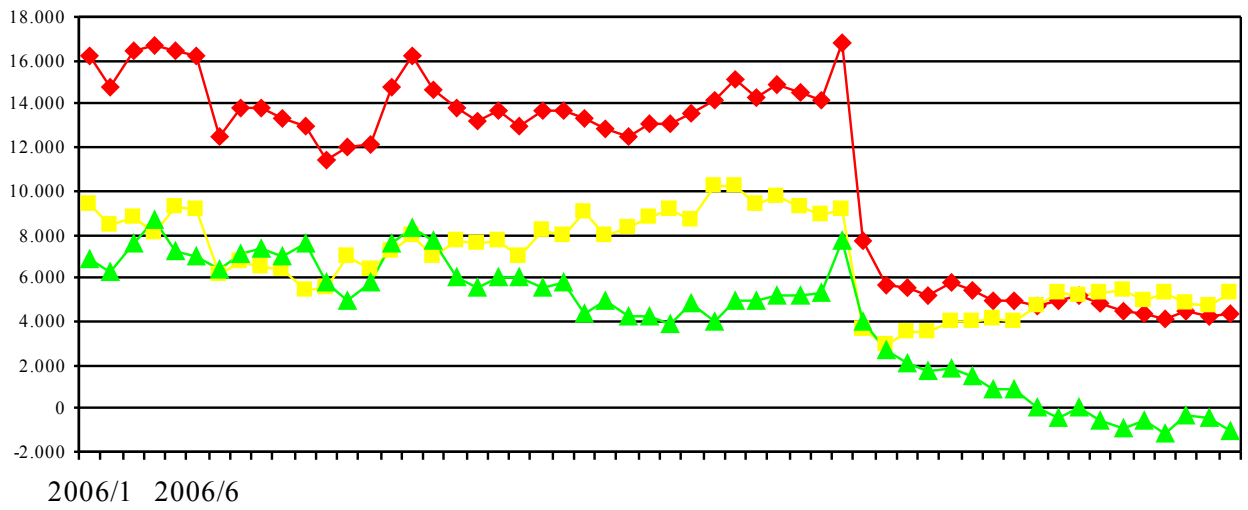

- loans to foreign banks $\longrightarrow$ credits and deposits taken from foreign banks $\longrightarrow$ net position

Figure 5. Slovakia: net position vis-á-vis foreign banks (2006-2010, mil. EUR) Source: The National Bank of Slovakia 
In the Czech Republic MFI loans are growing since 2004; banks started to pay more and more attention to households. While the share of non-financial corporations on credits decreased from more than $70 \%$ at the beginning of 90-ies to 30,75\% (May 2010), during the same period the share of credits to households increased from less than $5 \%$ to $39,02 \%$ (European Central Bank, 2010a). The growth of loans ended in October 2008 but after a two months decline we can see a mild growth of MFI total loans again. In comparison to Slovakia there was a three months decrease in lending for house purchase starting in November 2008 in the Czech Republic and a standstill until now. Most studies argue that a credit boom in central European countries caused growth of asset prices, above all growth of real estates and led to housing price bubble. But in the Czech Republic the size of the housing price overvaluation in $2007 / 2008$ was relatively low, as the rise in property prices in this period was largely explainable by fundamentals (Hlaváček and Komárek, 2009, p. 2).

The Czech Republic is a typical example of a country with mild and short-term impacts of recent financial crisis. The financial (banking) sector remained stable and foreign ownership of banks did not pass contingent difficulties of mother companies on their daughters. Banks became more cautious in risk evaluation of corporations, but loans to households including loans for house purchase are growing. Net position of MFI vis-á-vis foreign banks is stable for the whole period despite of financial crisis. While both loans to foreign banks and credits and deposits taken from foreign banks are growing until the second quarter of 2008, an inverse trend is under way until now (Figure 3).

In Poland financial sector was hit by financial crises very seriously but the impact was quite short. The drop in deposits started in August 2008 and month-by-month decrease finished after 7 months in February 2009. The amount of loans was growing until October 2008 and monthby-month decrease finished already in 4 months in March 2009. In June 2008 another important change happened in Poland: in MFI the amount of deposits started to be lower than the amount of credits. The fact that despite of financial crisis Poland was the only EU country that experienced a permanent GDP growth played an important role in this recovery. In March, 2009 growth of credits to households started based on growing consumption credits and credits to house purchase.

In three Visegrad countries very profitable banking sector became a source of dividends for their foreign owners. Banks also used sources for financing their activities abroad. In Slovakia until the end of 2009 loans to foreign banks were higher than credits and deposits taken from foreign banks. The net position (the difference between deposits taken from foreign banks and loans provided to foreign banks) of banks located in Slovakia changed in the end of 2009 (Figure 5). Permanently growing credits taken from foreign banks and decreasing loans to foreign banks resulted in negative net position starting October 2009. Similar situation appeared in Poland already at the beginning of 2007. In the Czech Republic the surplus of the net position vis-á-vis foreign banks stays for the whole period 2004-2010.

\section{Conclusion}

Most papers are based on an idea that bank lending flows (from advanced countries to the emerging market economies) represented a very important spillover effect of financial crisis and that international banks have been one of the major sources of finance for the catching-up process of the emerging market economies in recent years. Despite of many common features the recent developments have not been homogenous among regions (emerging markets in Asia, Latin America and Central and Eastern Europe) (Hermann and Mihaljek, 2010). Big disparities are among the particular countries in these regions, too.

In three Visegrad countries (Poland, Slovakia and the Czech Republic) that are usually presented as a part of central European countries or central and eastern European countries the sources of their financing from local banks were dominantly local. As comparison of deposits and loans of MFI confirms, as in most EU countries there is for the whole period 2006-2010 
close correlation between loans and deposits of MFI. This is one of main reasons of the stability of financial sector in three Visegrad countries and only mild impact of recent financial crises on their credit areas. The data about various types of credits and credit development do not confirm that firms in the Czech Republic or Romania were more credit constrained than firms in countries like Hungary or Poland because major portions of the banking market are held by the relatively undercapitalized Erste Group and UniCredit Group in comparison with the domestically-owned and well capitalized OTP and PKO (Popov and Udell, 2010, p. 28). At the beginning of the 1990s all former centrally planned countries had inefficient, underdeveloped banking sectors. Foreign banks played a very important role in recapitalizing troubled domestic banks, improving the quality and quantity of financial services, spreading technology and know-how, creating competitive environment in banking industry. Now in all transition countries in Europe banking sector is in hands of foreign capital with no important difference. The share of foreign capital in banking sector was at the end of $200869,2 \%$ in Poland, 81,0 \% in the Czech Republic, 86,4 \% in Hungary and 93,2 \% in Slovakia.

Our data concerning credit area absolutely confirm Gardó and Martin's conclusions. The recent crisis hit much more countries where loan-to-deposit ratio and external debt had been higher. What is important to underpin is that developments have not been homogenous among the countries. Large debt of MFI was not typical for the Czech Republic and Slovakia, depositto-loan ratio was $114,6 \%$ in the Czech Republic and 117,7 \% in Slovakia while it was 91,1\% in Poland (May 2010).

Credit growth in some countries was really elicited with capital inflows (maybe in Poland, but the Polish economy has been permanently growing) but in most countries there is a close relation between deposits and loans. So the growth of loans is above all the result of growing savings - in most countries households as well as companies answered the increasing instability the same way. At the same time the growth of loans is accompanied by serious change in structure of loans in all countries and regions.

The data confirm that stability of financial sector, the stability of banking industry is very high in all three Visegrad countries. Its stability is in close relation to stable development of savings and loans. It is understandable that increase of risks on the market during recent financial crisis influenced behavior of financial institutions. The negative impact on financial stability of financial industry was negligible while the impact on non-financial corporations was not harming nevertheless more serious.

\section{References}

- Barajas and Chami and Cosimano and Hakura, 2010. U.S. Bank Behavior in the Wake of the 2007-2009 Financial Crisis. IMF Working Paper, WP/10/131. IMF, Washington, D.C.

- Debrun and Mathisen, 2010. Europe Moving to Restore Growth and Sustainability. IMF Survey Magazine: Countries \& Regions, May 11.

- European Central Bank, 2010a. Statistical Data Warehouse, http://sdw.ecb.europa.eu/

- European Central Bank, 2010b. The Application of State Aid rules to Government Guarantee Schemes Covering Bank Debt to be Issued after 30 June 2010, http://ec.europa.eu/competition/state_aid/ studies_reports/phase_out_bank_guarantees.pdf

- Gardó and Martin, 2010. The impact of the global economic and financial crisis on central, eastern and south-eastern Europe. A stock-taking exercise. Occasional Paper Series, No. 114 / June 2010. ECB, Frankfurt am Main: 2010.

- Hermann and Mihaljek 2010. The determinants of cross-border bank flows to emerging markets: new empirical evidence on the spread of financial crises. BIS Working Papers, No. 315. BIS, Basel. 
- Hlaváček and Komárek, 2009. Housing Price Bubbles and their Determinants in the Czech Republic and its Regions. Working Paper Series 12/2009. Czech National Bank, Prague.

- NBS, 2010a. Analysis of the Slovak Financial Sector for the Year 2009. 2010. NBS, Bratislava.

- NBS, 2010b. Makroprudenciálna analýza slovenského bankového sektora. Marec 2010. NBS, Bratislava.

- Popov and Udell, 2010. Gross-border Banking and the International Transmission of Financial Distress during the Crisis of 2007-2008. Working Paper Series 1203/June 2010. ECB, Frankfurt. 